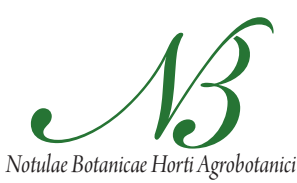

Cluj-Napoca

\title{
Dendroclimatic Response Variability of Quercus species in the Romanian Intensive Forest Monitoring Network
}

\author{
Ionel POPA ${ }^{1,2}$, Stefan LECA ${ }^{1,4^{*}}$, Adam CRĂCIUNESCU $^{3}$, Cristian SIDOR ${ }^{1}$, Ovidiu BADEA ${ }^{1,4}$ \\ ${ }^{1}$ Forest Research and Management Institute, Bld. Eroilor, 128, Voluntari,Romania; leca_d_stefan@yahoo. \\ com(*correspondingauthor),popaicas@gmail.com,cristi.sidor@yahoo.com,obadea@icas.ro \\ ${ }^{2}$ Stefan cel Mare University of Suceava, Forestry of Faculty, 13 Universității Street, Suceava, Romania \\ ${ }^{3}$ Banat University of Agricultural Science and Veterinary Medicine Timişoara, Faculty of \\ Horticulture and Forestry, Timișoara, Romania; adam_crăciunescu@yahoo.com \\ ${ }^{4}$ Transilvania University of Brasov, Faculty of Silviculture and Forest Engineering, Brasov, Romania
}

\begin{abstract}
Oaks are among the most important broad-leaved species in Romanian forests from both an economic and socio-ecological point of view. A significant decline of these species has been observed, which was first evident in various studies and investigations followed by the more results of interdisciplinary research performed in intensive monitoring plots (level II) showing that the decline is climate induced. Thus, it is important to understand the climate change conditions and factors that influence Quercus spp. Typical dendroclimatological investigations were conducted on an intensive forest monitoring network based on four oak species (Q. robur, Q.petraea, Q.cerris, and Q. frainetto) in 7 permanent plots placed in southern Romania. Three patterns of climate-growth relationships were identified and discerned in accordance with the Quercus species. All oak species were found to have a positive correlation with the level of precipitation. In addition, the intensity and level of significance of correlation coefficients differ from one species to another and from one region to another.
\end{abstract}

Keywords: climate change, dendroclimatology, intensive monitoring, oak, southern Romania

\section{Introduction}

The negative impact of environmental factors on forests was similar in Romania as that described in most European countries, where damage and abnormal dieback have become progressively predominant (Badea et al., 1998). This process first involved oaks (between $1937-$ 1943, 1947-1949, and 1955-1958) followed by other species, such as silver fir, pine, beech, and black locust between 1970-1978 and 1984-1994 (Badea et al., 1998). In order to clarify some of the aspects connected to this phenomenon, a series of studies and investigations were initiated. Between 1979 and 1990, interdisciplinary research on the causes of dieback of Quercus spp. were initiated (Alexe, 1986), which were finalized in a results-based system of measures needed to re-establish the ecological balance of these forest ecosystems.

At the same time, between 1977 and 1990 Ianculescu et al. (1990) studied the impact of air pollution on forest growth by dendrometric measurements, soil analyses, and assessments of other stress factors (climate, biotic, and abiotic). They established the losses in growth as a function of damage intensity (damage class) for Austrian pine (Pinus nigra), sessile oak (Quercus petraea), and beech (Fagus sylvatica). Changes in diameter, height, and volume growth were studied, enabling the scientists to approximate the economic losses in wood mass due to different stress factors (climate, air pollution, and anthropogenic). In addition, other studies assessed fir dieback (Barbu, 1991) due to water stress, soil as a possible cause of fir dieback (Bândiu, 1986), the influence of climatic factors on the dieback phenomenon, and droughts during the period of 19781987 and their influence on damage to these tree species (Geambasu, 1988).

At the international level, the decline of forest ecosystem status reported in the 1980s was highlighted through large scale research on the dynamics of trees stands and their growth. The results clearly demonstrated that air pollution, climate change, and different biotic and abiotic factors had a negative influence on forest growth and health (Badea and Neagu, 2010). Based on these results, most European countries have since initiated specific investigations on the long-term monitoring and research of forests under the action of various stress factors, especially air pollution and climate change, through special European research programs (ICP-Forests of UN/ECE, EU Scheme, Forest Focus Scheme, and Life+ Regulation). The main purpose of large scale forest monitoring (level I) was to determine the dynamics and spatial distribution of the tree damage 
process and analyze a long-term data series on forest health status and vitality.

An intensive monitoring system (level II) was subsequently implemented for permanent and continuous data collection in order to gain a better understanding of the integrated and cumulated actions of different stress factors. Over a period of several years, these two survey levels were developed, particularly with regard to the gathering of general information on the annual status of forest health (level I) and integrating multi-disciplinary research of representative forest ecosystems (level II). In Romania, a survey system for monitoring and controlling the quality of environmental factors of a forest was implemented and applied in accordance with the ICP-Forest Program at level I (in 1990) and at level II (in 1991-1992) (Badea, 1998; Patrascoiu and Badea, 1992).

A synthetic indicator of the influence of various factors on the status of forest health is tree growth, while the dynamics of tree crown defoliation are related to their physiological status tendency. Research conducted in a level II monitoring system found that Quercus spp. had the lowest values of growth with the most significant factor being the lack of precipitation (Badea and Neagu, 2007). Since the initiation of a monitoring system in Romania (1990), the information collected every year has shown that the most affected species are represented by the xerophilous oaks (Quercus pedunculiflora + Quercus pubescens) and Quercus frainetto for which the percentage of damaged trees (crown defoliation $>25 \%$ ) in 1994 was $42.6 \%$ and $45.5 \%$, respectively, followed by Robinia pseudoacacia (39.0\%), Quercus robur (30.5\%), Quercus cerris (30.6\%), and Quercuspetraea (30.7\%) (Badea and Neagu, 2007).

An understanding of the climatic factors that have a significant influence on radial growth processes is essential for forecasting the dynamics of forest health (as assessed by growth), taking into account the increase in the intensity of the climate change process (Schweingruber, 1996). Thus, the objective of this study was to identify the main meteorological factors that have a significant influence on radial growth processes with an emphasis on the climate response patterns for each oak species.

\section{Material and methods}

Study area

In Romania, as in most of the ICP-Forest's countries, a number of 13 long-term monitoring plots were selected Tab. 1. Study plots characteristics for intensive and integrated data collection related to the forest ecosystem status in order to determine the influence of different stress factors, especially air pollution and climate changes (Badea, 1998). This action contributed to a better understanding of the multi-disciplinary scientific research on the main representative forest ecosystems in Romania. The level II monitoring network was placed in different climate conditions and air pollution intensity values for that period (1991-1992). For this study, 7 intensive monitoring plots represented by oak species were investigated (Tab. 1).

These selected permanent sample plots are representative for the Southern part of Romania, and their dynamics accurately reflect oak forest development in the region. Oaks are keystone species in a wide range of habitats from Romania. The oak species included in the study has different ecological requirements. Q. cerris and Q. frainetto are xerophyllous species with high tolerance to drought. $Q$. petraea is less pretention from summer heat, but does not tolerate excessive continental climate and long term water deficit. Q. robur is adapted to continental climate with high requirement to summer heat.

\section{Data set}

From each site $25-40$ corers were extracted with a Pressler increment borer from each diameter class following standard dendrochronological procedures (Popa, 2004). Tree ring width measurements were performed using CooRecorder 7.4 software (Larsson, 2012) with an accuracy of $0.01 \mathrm{~mm}$. Measurement checking and crossdating were conducted with COFECHA (Holmes, 1983) and TSAP software (Rinntech, 2005). Each individual raw series was transformed to a growth index by detrending with a cubic smoothing spline and $50 \%$ frequency response cutoff that was equal to $67 \%$ of the series length (Cook and Kairiukstis, 1990). The mean chronology for each site was obtained using the biweight robust mean, and the residual autocorrelation was removed using an autoregressive model. Data processing was performed with the software ARSTAN (Cook and Krusic, 2007).

In order to use a homogeneous climate dataset, CRUTS 3.0 with a $0.5^{\circ} \times 0.5^{\circ}$ grid resolution was adopted (Mitchell and Jones, 2005). For each site, climate data (mean monthly temperature and total monthly precipitation amount) from the closest grid were extracted.

\begin{tabular}{cccccccc}
\hline No. & SSI name & & Latitude & Longitude & Altitude $(\mathrm{m})$ & Species & Age (years) \\
\hline 1 & Giurgiu & GIRA & $44^{\circ} 04^{\prime} \mathrm{N}$ & $26^{\circ} 03^{\prime} \mathrm{E}$ & 90 & Quercus cerris & 51 \\
2 & Videle 1 & VIDA & $44^{\circ} 18^{\prime} \mathrm{N}$ & $25^{\circ} 36^{\prime} \mathrm{E}$ & 100 & Quercus cerris & 56 \\
3 & Videle 2 & VIDB & $44^{\circ} 18^{\prime} \mathrm{N}$ & $25^{\circ} 36^{\prime} \mathrm{E}$ & 100 & Quercus frainetto & 56 \\
4 & Stefănești & STFA & $44^{\circ} 30^{\prime} \mathrm{N}$ & $26^{\circ} 10^{\prime} \mathrm{E}$ & 86 & Quercus robur & 61 \\
5 & Ploiești & PLOA & $44^{\circ} 54^{\prime} \mathrm{N}$ & $26^{\circ} 06^{\prime} \mathrm{E}$ & 150 & Quercus robur & 45 \\
6 & Câmpina & CAMA & $45^{\circ} 06^{\prime} \mathrm{N}$ & $25^{\circ} 42^{\prime} \mathrm{E}$ & 520 & Quercus petraea & 62 \\
7 & Mihăești & MIHA & $45^{\circ} 01^{\prime} \mathrm{N}$ & $24^{\circ} 59^{\prime} \mathrm{E}$ & 500 & Quercus petraea & 62 \\
\hline
\end{tabular}


328

Climate response analysis

To quantify the climate-growth relationship, statistical analysis for the mean monthly temperature and total monthly precipitation were used. The analysis period began in September of the previous year $(t-1)$ and extended until August of the current growing season $(t)$.

Tree response to climate variation was analyzed by Pearson correlation coefficients, and the statistical significance was evaluated using the bootstrap method (Efron, 1979). For data processing, the DENDROCLIM 2002 program (Biondi and Waikul, 2004) was used. All statistical analysis was performed for the common period of all series and for available climatic data (1950-2009). Principal component analysis (PCA), which was based on a covariance matrix, was used to separate different dendroclimatic patterns (Legendre and Legendre, 1998), and data processing was performed with XIStat software (Addinsoft, 2012).

\section{Results and discussion}

Growth series indices for Quercus spp. in intensive monitoring plots

The mean radial growth ranged from 1.5 to 1.6 $\mathrm{mm} \cdot \mathrm{year}^{-1}$ for Q. cerris and from 2.2 to $2.3 \mathrm{~mm} \cdot \mathrm{year}^{-1}$ for Q. robur. The least growth was noted for $Q$. frainetto (1.5 $\left.\mathrm{mm} \cdot \mathrm{year}^{-1}\right)$ and the highest occurred with $Q$. petraea $(2.0$ to $\left.2.4 \mathrm{~mm} \cdot \mathrm{year}^{-1}\right)$. The oak species from the forest steppe region showed a maximum sensitivity range of 0.42 to 0.49 compared to 0.31 for Q. petraea in the forest region. The influence of the previous year's mean growth on all Quercus spp. was noticeable, as reflected by the first order autocorrelation (0.5 to 0.6). Notably, there was high homogeneity with the individual datasets, which was highlighted by the average correlation coefficient of the individual series with chronology. These mean correlation coefficients had a value of over 0.7 , indicating that they were highly statistically significant (Tab. 2).

The dynamics of the growth indices series showed maximum agreement among the dendrochronological series of the same species, but also a similar variation among species. This is particularly evident with the positive or negative extreme years. For all oak species, the common extreme negative years were 1981, 1968, 2002, and 2007, and the common positive years were 1969, 1984, 1991, 2005, and 2010.

Periodical dendrometric measurements in the intensive forest monitoring system showed that the lowest values of annual growth average $\left(2.32-2.97 \mathrm{~m}^{3} \cdot \mathrm{ha}^{-1}\right)$ were recorded in Q. robur stands located in the southern part of Romania (Giurgiu, Ploiesti, Stefanești). For Q.petraea, the mean values of annual growth were almost normal $\left(5.61 \mathrm{~m}^{3} \cdot \mathrm{ha}^{-1}\right.$ in Campina and $6.46 \mathrm{~m}^{3} \cdot \mathrm{ha}^{-1}$ in Mihaesti) (Badea and Neagu, 2010). These mean annual growth values recorded in the south and southeast regions of Romania are considered subnormal due to excessive drought conditions between 1981 and 1994 as well as in 1998, 2000, and 2002-2004. Thus, these species have exhibited considerable resistance to the extreme climatic conditions in southern Romania (Badea and Neagu, 2007).

\section{The relationship between climatic factors and growth indices}

Correlation analysis between growth indices and rainfall events showed a similar pattern of dendroclimatic response (Fig. 2). Regardless of the year period, the systematically positive correlation of growth indices with precipitation is specific for Quercus spp. from the study area. However, there are differences from one species to another and from one region to another with regard to the level and significance of the correlation coefficients.

For $Q$. cerris and $Q$. frainetto, the positive influence of the precipitation regime was more evident than for $Q$. robur and Q. petraea, indicating a high sensitivity to the frequency and intensity of drought periods. For $Q$. petra$e a$, a significant correlation with rainfall was observed for the previous autumn (November) and winter (January) seasons, with a direct influence on the soil hydrological regime at the start of the spring growth processes.

Precipitation (rain or snow) increases the radial growth of oaks by enhancing ground water and improving the water supply during the spring (Cedro, 2007). In the western part of Poland, the precipitation from December of the

Tab. 2. Statistical parameters of the Quercus spp. dendrocronological series from the level II monitoring network

\begin{tabular}{cccccccc}
\hline \multirow{2}{*}{ Statistical parameter } & \multicolumn{2}{c}{ Q.petraea } & \multicolumn{2}{c}{ Q. robur } & \multicolumn{2}{c}{ Q. cerris } & \multicolumn{2}{c}{ Q. frainetto } \\
\cline { 2 - 8 } & CAMA & MIHA & PLOA & STFA & GIRA & VIDA & VIDB \\
\hline Chronology length & $1939-2012$ & $1927-2012$ & $1956-2012$ & $1941-2012$ & $1903-2012$ & $1928-2012$ & $1947-2012$ \\
$\begin{array}{c}\text { Chronology length with } \\
\text { more than 10 cores }\end{array}$ & $1951-2012$ & $1945-2012$ & $1957-2012$ & $1943-2012$ & $1925-2012$ & $1954-2012$ & $1949-2012$ \\
\hline No. of cores & 36 & 31 & 42 & 43 & 40 & 41 & 24 \\
Mean tree ring width (mm) & 2.401 & 1.949 & 2.324 & 2.174 & 1.543 & 1.582 & 1.495 \\
Standard deviation & 0.298 & 0.289 & 0.414 & 0.285 & 0.43 & 0.446 & 0.39 \\
Mean sensitivity & 0.319 & 0.315 & 0.422 & 0.329 & 0.415 & 0.496 & 0.426 \\
\hline First order autocorrelation & 0.616 & 0.612 & 0.528 & 0.671 & 0.541 & 0.498 & 0.567 \\
Rbar & 0.472 & 0.406 & 0.558 & 0.526 & 0.662 & 0.679 & 0.58 \\
\hline Correlation with chronology & 0.74 & 0.676 & 0.721 & 0.758 & 0.75 & 0.73 & 0.752 \\
\hline
\end{tabular}




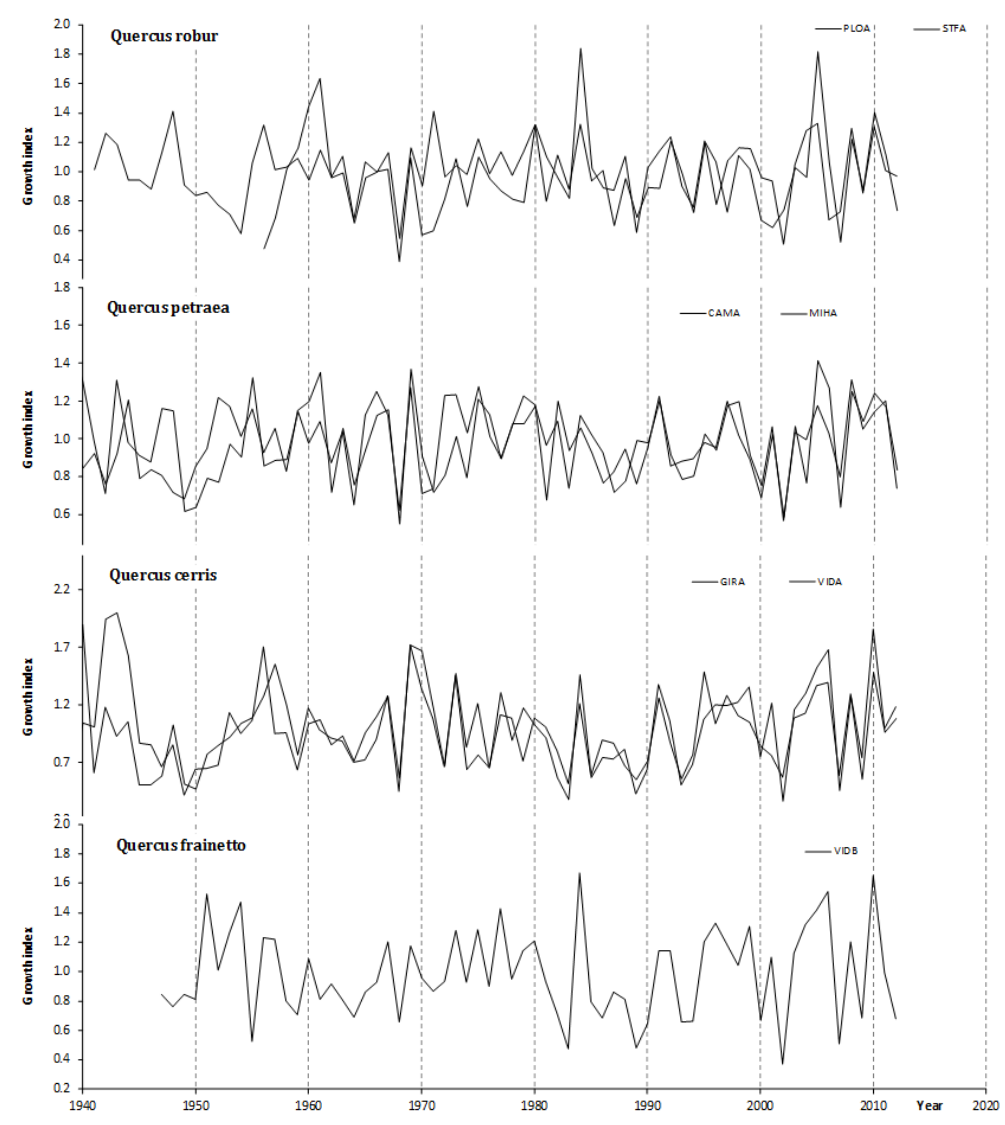

Fig. 1. Dendrochronological series for oak species from the forest intensive monitoring network (codes of sites according with Tab. 1)

previous year represents the variable with the greatest influence on $Q$. petraea radial growth processes. For $Q$. robur, the growth process is highly influenced by the rainfall of the previous autumn (Cedro, 2007). In the western part of France, $Q$. robur has a positive response to precipitation mainly from October to November of the previous year as well as May of the current growing season (Lebourgeois $e t$ al., 2004).

At the study area level, precipitation during the growing period (April-June) had a positive and statistically significant influence on $Q$. petraea, especially in the experimental plot Mihaesti, compared to Q. robur. Soil water deficit, which is directly affected by the precipitation regime, represents the main factor in radial growth for $Q$. cerris and Q. frainetto in southern Romania. For both species, most of the months of the year are significantly correlated with radial growth indices. In both cases, the greatest influence on tree biomass accumulation is represented by precipitation during the late winter and early spring. A similar finding was observed for Q. cerris located in central Italy, which responds primarily to spring precipitation (Romagnoli and Codipietro, 1996). Another important variable for the radial growth of $Q$. cerris in central Italy is the November rainfall from the previous year (Di Filippo et al., 2010).

Monthly mean temperature generally represents a negative factor for tree ring formation processes, especially in terms of deepening processes of evapotranspiration as determined by the lack of precipitation during the growing season (Fig. 3). For Q. petraea and Q. robur, a positive correlation between the growth indices and temperature was observed from November to January, which was statistically significant for $Q$. robur in December.

High temperatures in March and water stress during May to July are the main limiting factors for the radial growth of Q. robur located in northern France (Merian et al., 2011). However, this was not observed for Q. robur located in other regions throughout Europe (Cedro 2007; Dolezal et al., 2010; Friedrichs et al., 2009a,b; Lebourgeois et al., 2004). Of the four oak species analyzed in Romania, Q. cerris demonstrated a significant negative response to March temperatures. Q. petraea had a negative response mainly to summer temperatures (June-July) and Q. robur had a negative response in late spring. In addition, $Q$. frainetto showed no significant response to thermal regime changes. The climate during late spring and early summer has a significant influence on the formation and size of late wood, which is closely correlated with total variation in tree ring width (Akkemik et al., 2006; Corcuera et al., 2004).

After recording the highest percentage of damaged trees in 1994 as a result of over 15 years of prolonged drought, particularly for main species such as oak, a slight improvement in the status of forest health was observed 
330

during the 1995-1999 period, which correlated with the increase in precipitation levels beginning in the summer of 1994 and ending in 1998. Small fluctuations (increase or decrease) in the status of forest health were then observed until 2002. However, in 2003 due to strong drought produced not only in Romania but also in all of Europe (UN/ECE) (Badea and Neagu, 2007), the intensity of the damage process was relatively strong, resulting in a high percentage of damaged Quercus spp. (37.9\% for Q. pubescens + Q. pedunculiflora, $35 \%$ for Q. frainetto, $22.7 \%$ for Q. cerris, and $21.7 \%$ for $Q$. robur). Beginning in the 20042005 period, the crown condition for oak species had a lower damage intensity (a noted improvement compared to previous years), which was due to the increased number of rainfall events. Analysis of the forest health status dy- namics for a period of over 17 years (1990-2006) showed an immediate reaction for most species during the same growing-season with regard to the increasing or decreasing precipitation levels recorded in the spring of each year. For Q. robur, a much slower reaction to the variation in precipitation levels was noticed. This reaction might occur over a minimum period of 2-3 years (Badea et al., 2003, 2011).

\section{Climate response patterns}

PCA analysis related to the dendrochronological series as variables and correlation coefficients with temperature and precipitation as observations allow for the differentiation of three specific types of dendroclimatic responses for each Quercus spp. (Fig. 4). The sensitivity of each oak species to climate is strongly reflected by the site distribution
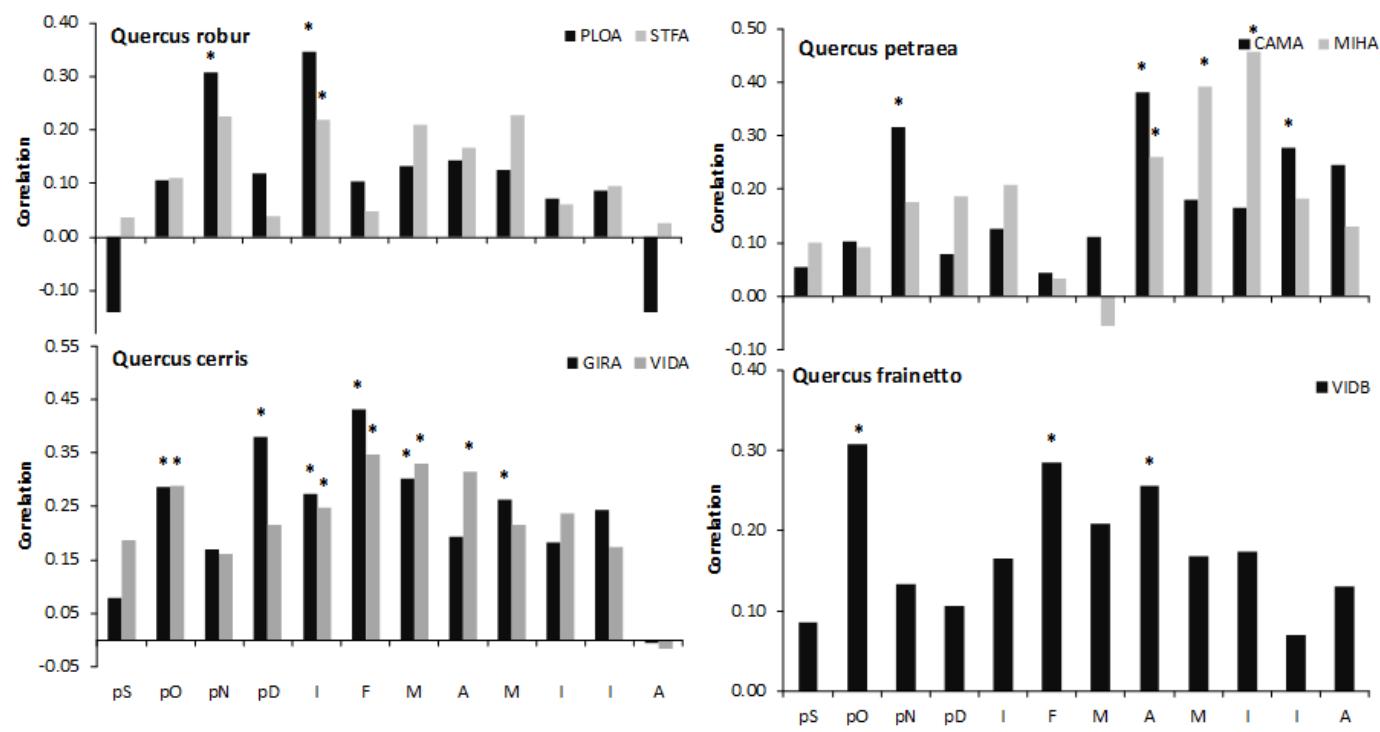

Fig. 2. Correlation between precipitation regime and growth indices (codes of sites according with Tab. 1; starts highlights statistically significant value)
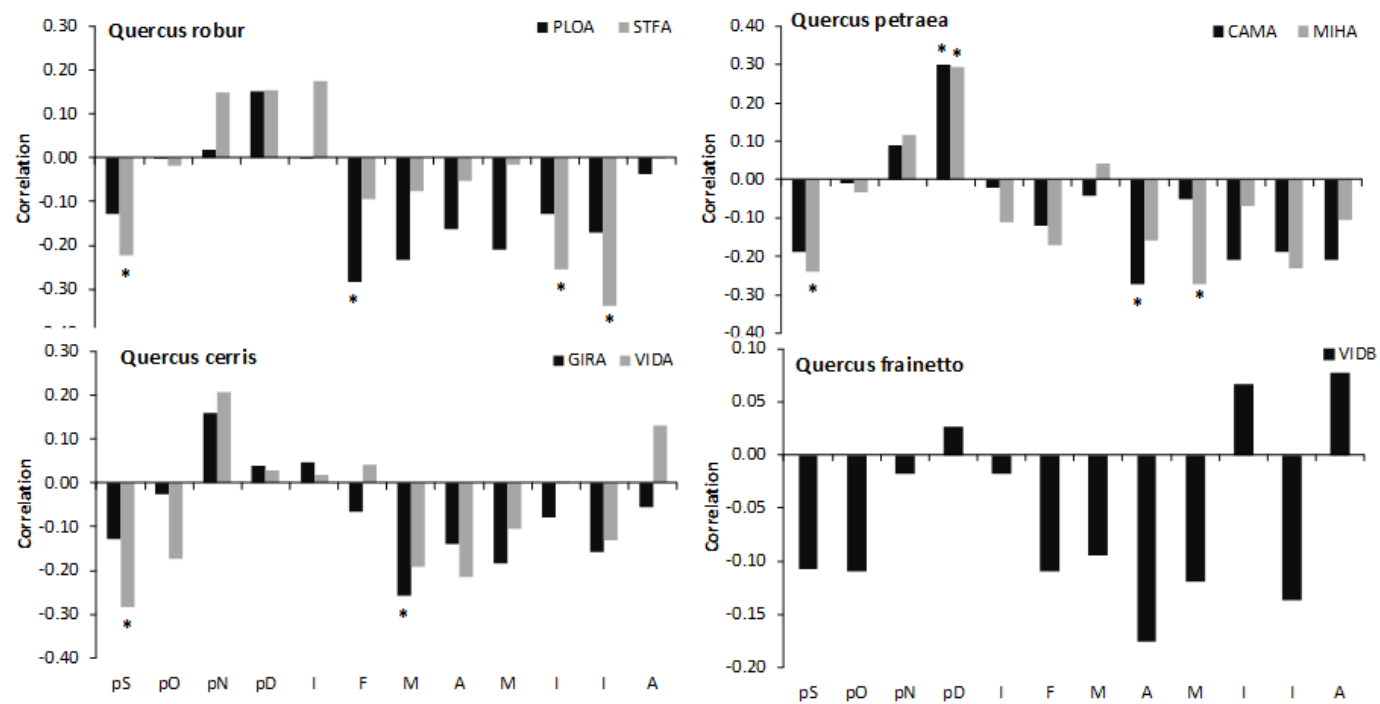

Fig. 3. Correlation between thermal regime and growth indexes (codes of sites according with Tab. 1; starts highlights statistically significant value) 


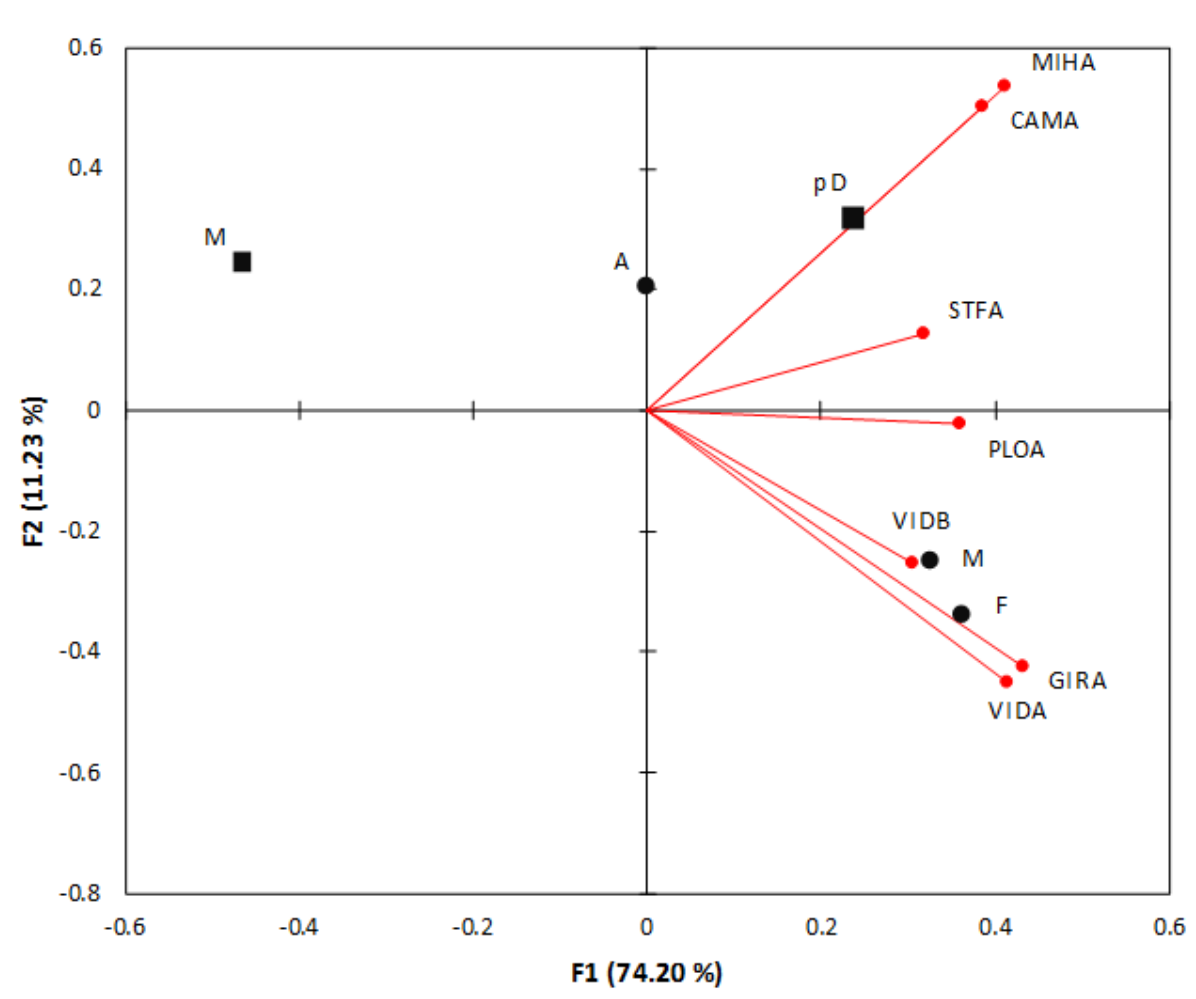

Fig. 4. PCA biplot analysis of correlation coefficients with climatic factors (temperature and precipitation)

on the second PCA axis. All chronologies show positive coefficients on axis 1 , indicating a joint contribution to its formation. This emphasizes that in general, the oak species respond to the same combination of climatic factors. Thus, the correlation intensity is the factor that lead to differentiation in the climatic response model.

One type of climate response specific for Q. robur can be described by the positive correlation with precipitation between April and June, and the differentiation from other species of oak occurs by the significant and positive correlation with temperatures in December. At the opposite side, the specific dendroclimatic model response of Q. cerris and Q. frainetto is characterized by the strong and statistically significant influence caused by the previous autumn and current growing season precipitation. $Q$. petraea and Q. robur are differentiated by the correlation with precipitation during the February-March period, and the specific response of $Q$. petraea is an intermediary between the two major types of responses discriminated by the PCA analysis.

Other studies have also observed that oak species display a specific climate-growth relationship that varies by species and region (Friedrichs et al., 2009; Lebourgeois et al., 2004; Merian et al., 2011).

\section{Conclusions}

In this study we found that drought in general, and particularly during the growing season, is the main limiting factor of radial growth for oak species in southern Ro- mania. The intensity of the correlation with regard to precipitation amount and the limiting period of the year are specific for each Quercus species. Three types of dendroclimatic patterns were delimited, and this is in accordance with the ecology of each oak species. Thus, such statistical studies related to the climate-growth relationship should be taken into account when the impact of climate change on forest ecosystems is studied.

\section{Acknowledgement}

This study was supported by Romanian Authority for Research in Core Program for forestry - GEDEFOR, project PN09460110 and partially by CNCS-UEFISCDI project number PN-II-RU-TE-2011-3-0040.

\section{References}

Addinsoft SARL (2012). XLSTAT software http://www.xlstat. com/en/download.html

Akkemik Ü, Çinar Yilmaz H, Sevgl O (2006). Cambial activity of the sessile oak (Quercus petraea) in Belgrade forest, Istanbul. Turkish J Agric For 30:429-438.

Alexe A (1986). Systemic analysis of the phenomenon and the causes of drying the cvercinee. Revista Pădurilor 101:19-23 (in Romanian).

Badea O (1998). Dendrometric and auxological fundamentals for forest monitoring. Universitatea „Ştefan ce Mare", Suceava, $177 \mathrm{p}$ (in Romanian).

Badea O, Neagu S (2007). Health of forests in 2006, in Roma- 
332

nia, measured by the national network of permanent survey $(4 \times 4 \mathrm{~km})$. Revista Pădurilor 5:11-17 (in Romanian).

Badea O, Neagu S (2010). Volume growth losses for trees and forest stands in the Romanian intensive monitoring system. Proceedings of the Romanian Academy, Series B: Chemistry, Life sciences and Geosciences 12:259-266.

Badea O, Neagu S, Leca S, Silaghi D, Iacob C, Guiman G, Teodosiu $M$ (2011). Increasing trees in forest monitoring system. Revista Pădurilor 3-4:28-34 (in Romanian).

Badea O, Pătrăşcoiu N, Geambaşu N, Barbu I, Bolea V (1998). Forest Condition Monitoring in Romania, Office National de Forest, Department des Recherches Techniques, 62 p.

Badea O, Pătrăşcoiu N, Tănase M (2003). Forest monitoring system in Romania, Dynamics of Romanian forest health status over the period 1990-2002. Analele ICAS 46:221228.

Barbu I (1995). Death of fir tree-symptom of environmental degradation. Ceres Ed., Bucuresti, 279 p (in Romanian).

Bândiu C (1986). Cercetări privind urmărirea fenomenului de uscare la brad. Referat ştiințific final, ICAS Bucureşti.

Biondi F, Waikul K (2004). DENDROCLIM2002: a C++ program for statistical calibration of climate signals in tree-ring chronologies. Computers \& Geosciences 30:303-311.

Cedro A (2007). Tree-ring chronologies of down oak (Quercus pubescens), pedunculate oak (Quercus robur) and sessile oak (Quercus petraea) in the Bielinek nature reserve: comparison of the climatic determinants of tree-ring width. Geochronometria 26:39-45.

Cook ER, Kairiukstis LA (1990). Methods of dendrochronology. Applications in the environmental sciences. Kluwer Academic Publishers, Dordrecht, 394 p.

Cook ER, Krusic PJ (2007). ARSTAN - a tree-ring standardization program based on detrending and autoregressive time series modeling, with interactive graphics. Tree-Ring Laboratory, Lamont Doherty Earth Observatory of Columbia University, Palisades, NY.

Corcuera L, Camarero JJ, Gil-Pelegrin E (2004). Effects of a severe drought on growth and wood-anatomical properties of Quercusfaginea. IAWA J 25:185-204.

Di Filippo A, Alessandrini A, Biondi F, Blasi S, Portoghesi L, Piovesan G (2010). Climate change and oak growth decline: Dendroecology and stand productivity of a Turkey oak (Quercus cerris L.) old stored coppice in Central Italy. Ann For Sci 67:706.

Dolezal J, Mazurek P, Klimesova J (2010). Oak decline in southern Moravia: the association between climate change and early and late wood formation in oaks. Preslia 82(3):289306.

Efron B (1979). Bootstrap methods: another look at the jackknife. The Annals of Statistics 7(1):1-26.
Friedrichs DA, Buntgen U, Frank DC, Esper J, Neuwirth B, Loffler $J$ (2009). Complex climate controls on $20^{\text {th }}$ century oak growth in Central-West Germany. Tree Physiol 29(1):3951.

Friedrichs DA, Trouet V, Buntgen U, Frank DC, Esper J, Neuwirth B, Loffler J (2009). Species-specific climate sensitivity of tree growth in Central-West Germany. Trees Struct Funct 23(4):729-739.

Geambaşu N (1988). Drought and drying phenomenon of some forest tree of Bucovina. Revista Pădurilor 2:72-80 (in Romanian).

Holmes RL (1983). Computer-assisted quality control in treering dating and measurement. Tree Ring Bulletin 43:69-75.

Ianculescu M, et al. (1990). Research on the dynamics of growth and damage assessment in stands under the influence of industrial pollution on the degree of injury. Scientific papers, of ICAS. (in Romanian).

Larson LA (2012). On-line user manual for Cybis CooRecorder and CDendro programs. http://www.cybis.se/forfun/ dendro/

Lebourgeois F, Cousseau G, Ducos Y (2004). Climate-treegrowth relationships of Quercus petraea Mill. Stand in the Forest of Berce (Futaie des Clos, Sarthe, France). Ann For Sci 61:361-372.

Legendre P, Legendre L (1998). Numerical ecology. $2^{\text {nd }}$ English edition. Elsevier Science BV, Amsterdam, 853 p.

Merian P, Bontemps JD, Berges L, Lebourgeois F (2011). Spatial variation and temporal instability in climate-growth relationships of sessile oak (Quercus petraea Matt. Liebl.) under temperate conditions. Plant Ecol 212:1855-1871.

Mitchell TD, Jones PD (2005). An improved method of constructing a database of monthly climate observations and associated high-resolution grids. International Journal of Climatology 25:693-712.

Pătrăşcoiu N, Badea O (1992). Technical and organizational concept of forest health surveillance recently implemented in the forests of Romania. Revista pădurilor 1:23-28. (in Romanian).

Popa I (2004). Methodological foundations and applications of dendrochronology. Tehnică Silvică Ed., Experimental Spruce Culture Research Center. Câmpulung Moldovenesc, $200 \mathrm{p}$.

Rinntech (2005). TSAP User reference, $110 \mathrm{p}$.

Romagnoli M, Codipietro G (1996). Pointer years and growth in Turkey oak (Quercus cerris L.) in Latium (central Italy). A dendroclimatic approach. Ann Sci For 53:671-684.

Schweingruber FH (1996). Tree rings and environment. Dendroecology. Birmensdorf. Swiss Federal Institute for Forest, Snow and Landscape Research. Berne, Stuttgart, Vienne, Haupt. 609 p. 